\title{
Article \\ Gender Dynamics in a Masculine Professional Context: The Case of the Portuguese Air Force
}

\author{
Maria Helena Santos ${ }^{1, *(D)}$, Patrícia Morais ${ }^{1}$ and Rita B. Correia ${ }^{2}$ \\ 1 Instituto Universitário de Lisboa (Iscte-IUL), CIS-IUL, 1649-026 Lisboa, Portugal; \\ patriciasoaresmorais96@gmail.com \\ 2 Instituto de Ciências Sociais da Universidade de Lisboa (ICS-IUL), 1600-189 Lisboa, Portugal; \\ ritacorreia@ics.ulisboa.pt \\ * Correspondence: helena.santos@iscte-iul.pt
}

check for updates

Citation: Santos, Maria Helena, Patrícia Morais, and Rita B. Correia. 2022. Gender Dynamics in a

Masculine Professional Context: The Case of the Portuguese Air Force. Social Sciences 11: 82. https:// doi.org/10.3390/socsci11020082

Academic Editor: Barbara Fawcett

Received: 12 January 2022

Accepted: 15 February 2022

Published: 17 February 2022

Publisher's Note: MDPI stays neutral with regard to jurisdictional claims in published maps and institutional affiliations.

Copyright: (c) 2022 by the authors. Licensee MDPI, Basel, Switzerland. This article is an open access article distributed under the terms and conditions of the Creative Commons Attribution (CC BY) license (https:// creativecommons.org/licenses/by/ $4.0 /)$.

\begin{abstract}
This article aims to understand the experiences of women working in the Portuguese Air Force, a traditionally male professional environment, and the perspectives of their male counterparts on the subject, considering women's minority status and symbolic gender asymmetries in the military. This study draws on 16 semi-structured interviews with Air Force personnel, evenly split by gender. Findings reveal four main themes that convey awareness that the Air Force is still a masculine world, perceptions of gender dynamics in the Air Force, barriers to equality, and strategies to address the situation. Although gender equality is formally in place in the Air Force, women continue to face obstacles that hinder their career advancement and ensure that their professional experiences differ from those of their male counterparts.
\end{abstract}

Keywords: Portuguese Air Force; tokenism; gender dynamics; inequality

\section{Introduction}

Women's participation in the workforce is at the heart of debates regarding gender equality and equality policy reform and continues to be a topic of increasing attention in both academia and the public sphere (Amâncio and Santos 2021; Casaca and Lortie 2017; Germain et al. 2012; Smith 2013; Ridgeway 2011). In the context of the military, many researchers argue that institutional practices are responsible for much of the gendered barriers women face in masculinized workplaces (Kanter 1993; Rimalt 2007). Central to this debate is the claim that organizations mobilize a masculine bias that is embedded in the hierarchical structure of the organization.

The imbalance of male and female professionals existing across the military is evident at the national (e.g., Carreiras 2004, 2006) and international levels (e.g., Evertson and Nesbitt 2004; Segal and Wechsler Segal 2004). As a result of conservative policies, social stereotypes, and a cultural framing that has resisted the integration of women, they have been historically under-represented in these institutions (Kronsell 2005; Carreiras 2011; King 2016). In fact, the military is a sector of severe gender segregation, both horizontal and vertical, since women are severely underrepresented in number (horizontal segregation) and at leadership positions (vertical or hierarchical segregation); for more on the topic of occupational discrimination, (see Bettio et al. 2009).

To understand women's and men's narratives regarding women's experiences in a field as extremely gendered as the Air Force, this paper draws on the analysis of qualitative interviews considering two theoretical perspectives-tokenism and gender studies. Although there is a growing body of literature on gender inequality and tokenism, there is little qualitative exploration of these combined topics in the military, where gender imbalance dynamics are historically prevalent. In fact, we were unable to find any studies providing an in-depth exploration of air force military women's experiences navigating this traditionally male-dominated environment and the perceptions of their male counterparts. 


\subsection{Historical and Contextual Background}

In 1961, the Air Force became the first branch of the Portuguese armed forces to allow women to serve in their ranks. Six female nurse parachutists participated in the Portuguese colonial war providing medical aid on the battlefield (Fachada et al. 2013). Their presence opened the way to the approval of the legal framework and the necessary regulations required for women's access to military service, namely via volunteer service. Nevertheless, in 1991, only 46 women signed up for the first time to the Air Force's New Recruits Training Program and, one year later, 11 women made it to the Officer's Training Program. By then, only one woman was enrolled in the Sargent's Training Program.

Female participation continued to rise across all ranks and specialized fields both in military careers and in temporary and voluntary contractual regimes (Fachada et al. 2013), and by 2010 , women represented $11 \%$ of the military personnel employed across the armed forces. The Air Force branch employed the highest percentage of female personnel (17.08\%), in proportion (Carreiras 2013), in 2010. Since then, the percentage of women across all branches of the Armed Forces has stabilized between $11 \%$ and $13 \%$, and specifically in the Air Force, between 15\% and 17\%. By 2018, 11,7\% of all military personnel and 15,9\% of all Air Force professionals were women (see Table 1).

Table 1. Number of militaries, by sex and branch, of the Portuguese Armed Forces between 2010 and 2018.

\begin{tabular}{ccccccccccc}
\hline \multirow{2}{*}{ Branch } & Sex & \multicolumn{10}{c}{ Year } \\
\cline { 3 - 11 } & & $\mathbf{2 0 1 0}$ & $\mathbf{2 0 1 1}$ & $\mathbf{2 0 1 2}$ & $\mathbf{2 0 1 3}$ & $\mathbf{2 0 1 4}$ & $\mathbf{2 0 1 5}$ & $\mathbf{2 0 1 6}$ & $\mathbf{2 0 1 7}$ & $\mathbf{2 0 1 8}$ \\
\hline \multirow{2}{*}{ Navy } & Female & 846 & 812 & 839 & 876 & 825 & 819 & 842 & 812 & 876 \\
& Male & 8347 & 7824 & 7819 & 7948 & 7656 & 7175 & 7140 & 6893 & 7043 \\
\hline \multirow{2}{*}{ Army } & Female & 2510 & 2197 & 2066 & 2102 & 1749 & 1530 & 1363 & 1274 & 1316 \\
& Male & 15,080 & 14,515 & 15,571 & 15,625 & 14,371 & 13,596 & 13,316 & 12,217 & 11,567 \\
\hline \multirow{2}{*}{ Air } & Female & 1135 & 1097 & 1036 & 1068 & 950 & 929 & 916 & 884 & 942 \\
Force & Male & 5512 & 5361 & 5307 & 5470 & 5181 & 5167 & 5069 & 4987 & 4968 \\
\hline \multirow{2}{*}{ Total } & Female & 4491 & 4106 & 3941 & 4046 & 3524 & 3278 & 3121 & 2970 & 3134 \\
& Male & 28,939 & 27,700 & 28,697 & 29,043 & 27,208 & 25,938 & 25,525 & 24,097 & 23,578 \\
\hline
\end{tabular}

Source: General Directorate of National Defense Resources / National Ministry of Defense.

\subsection{Tokenism and Beyond: Adding Contributions of Gender Perspectives}

Due to the aforementioned persistent underrepresentation, women in Portuguese military forces and in the Air Force are at higher risk of tokenism as defined by Kanter (1993). In her seminal work (Kanter 1977, 1993), she states that in a professional context that involves "skewed groups", the proportionally scarce workers (i.e., the tokens, representing $15 \%$ or less of the total group by any important category such as sex) face greater difficulties in the workplace than their peers in the "dominant" group (in this case, men) and are correspondingly treated as symbols or representatives of their category rather than as independent individuals. According to this same author (Kanter 1977, 1993), the proportional rarity of tokens interlinks with three perceptual tendencies: Visibility, contrast, and assimilation. These perceptual tendencies, in turn, tend to generate typical responses on behalf of the tokens that may lead to negative consequences for them: Visibility tends to create performance pressures; contrast leads to the heightening of dominant culture boundaries, including isolation of the token; and assimilation results in the token's role encapsulation, a kind of role imprisonment.

Following the work of Kanter $(1977,1993)$, research on women and tokenism took place in various professional settings in the United States, such as in the Police Forces (Ott 1989), the medical field (Floge and Merrill 1986), firefighting (Yoder and McDonald 1998), law graduation programs (Spangler et al. 1978), and in military ranks (Yoder et al. 1983). In Portugal, the subject has also been a target of research, addressing female scien- 
tists (Amâncio 2005), female military professionals (Carreiras 2004), female police officers (Almeida 2006; Delgado 2016), female politicians (Santos et al. 2016), and male and female doctors (Santos et al. 2015). Some aspects of the first examples of research of women as tokens (e.g., Spangler et al. 1978; Yoder et al. 1983) backed Kanter's argument: Yoder et al. (1983) described how the first women to join the West Point Military Academy expressed a perception of excessive visibility, certain social isolation, and the attribution of undervalued executive functions or were out of contention.

Tokenism was a particularly significant theoretical contribution because it highlighted the importance of organizational structure and context in explaining the underrepresentation of women in positions of influence in corporations (Santos and Amâncio 2014). Previously, most explanations of gender inequality relied on dispositional and internal reasons (see Yoder 1994). Yet, critics of Kanter's theory dispute the notion that numerical rarity is the sole cause of mistreatment of minority groups, but rather that it speaks to larger macrosocial power relations in the broader society.

In fact, Kanter's perspective alone could not adequately explain all the complexities of the gender dynamics between men and women in their workplace experiences, since it does not integrate the historical and social power dynamics of gender inequalities (Santos and Amâncio 2014). Subsequent research in different professional contexts (e.g., Budig 2002; Cognard-Black 2004; Floge and Merrill 1986; Heikes 1991; Williams 1992, 1995; Yoder 1991; see Watkins et al. 2019, for a review) contest the overgeneralization of her results to all social groups, disregarding these social dynamics, and demonstrated the shortcomings of analysis based only on proportional representation.

The integration of a gender perspective in Kanter's contributions allows an exploration of how the social status of a group might determine the experiences deriving from that token status (minorities). From this point of view, exploring the experiences of men (who socially tend to hold a position of higher status) in traditionally female occupations may differ from the experiences of women (members of social lower status in terms of gender power dynamics) in male-dominated professional areas. By questioning the neutrality of gender on tokenism, the gender perspective (e.g., Acker 1990; Williams 1995) maintains that organizations and their workers are influenced by gendered social power dynamics, and very often preserve and reproduce in their core and in their workplaces the same gender order that prevails in society (Connell 2002, 2006). This gender order, by the definition of the symbolic asymmetry model (Amâncio and Oliveira 2006), is based on a shared system of values where masculine individuation and feminine deindividuation are prevalent (Amâncio 1997), which divides the gender categories as men-as a universal point of reference-and women-as a gendered category limited within the private scope of caring (in the family, in the domestic sphere, in education). Further considering genderasymmetric power (Lorenzi-Cioldi 1998) and the effects of symbolic relations (Amâncio 1997; Amâncio and Oliveira 2006), men (as members of a dominant group) are perceived as the archetypical individual and universal reference for what is a "human being", and by extension, what is a "professional". This conceptualization goes beyond the effects of organizational culture, and women (as members of the social devaluated group), when considered as professionals, are a reference only within their group, and even in that role are frequently expected to exhibit female traditional stereotypical traits and attitudes and consequently subjected to the norms of female stereotypes. This symbolic asymmetry approach (Amâncio 1997; Amâncio and Oliveira 2006), considers the role of token women differently from the role of token men in professions where those are a minority. Women have more negative outputs and gain fewer advantages from their "token" role in their "atypical" contexts (i.e., traditionally masculine roles), than men in traditionally female roles. That is the case of the military, including the Portuguese Air Force (Carreiras 2006).

Within this framework, it is hardly surprising that Carreiras (2004) confirmed the existence of tokenism in a study carried out with female officers within the context of the Portuguese and Dutch armed forces. In fact, an analysis of 29 interviews underpinned several issues: Excessive visibility (with reference to the pressures that women feel as 
tokens); a tendency to be over-complying with superior requests; the fear of disproportional punitive actions as a result of small errors; and specific issues that women associated with being a woman in the military. Women feel that the amplification of minor job errors was not counterbalanced by the same amplification in the case of positive outputs and was not equally prevalent within their male colleagues where these minor events tended to go unnoticed. Moreover, women perceived a polarization of the differences between them and men that works to their disadvantage (e.g., openly emphasizing their presence and the need to be particularly attentive to language). Even though women acknowledged some positive outcomes of their presence in the military, in terms of changes in the formality of the military environment, they still refer to negative consequences such as social isolation and exclusion from informal socialization events. Women frequently express the perception of widespread bias among their colleagues, expecting stereotypical female traits from every woman. Their status was also frequently mentioned as responsible for their failure to address situations of harassment since women felt pressure to be accepted and gain recognition as serving in the military. When women adopted traditional "masculine" behaviors, such as being more aggressive or overly assertive, they are, again, frequently criticized for not acting like "women" (Carreiras 2004).

With this framework in mind and considering the scarcity of research on gender in the military field, particularly in the Air Force, this article aims to analyze the experiences of women in this professional context considering the concept of tokenism (Kanter 1977, 1993) and the effects of symbolic gender asymmetries (Amâncio 1997; Amâncio and Oliveira 2006), as well as the perspectives of their male counterparts on the subject. Considering our aim and our theoretical framework, our goals are to understand, in particular:

- Whether women see themselves in a token position and what themes emerge from their interviews, as well as from the narratives of their male counterparts;

- How this position is affected by the complexity of social dynamics between the sexes;

- How women and men perceive Air Force efforts to enforce gender equality;

- What strategies women employ to manage their military roles within this framework.

\section{Methods}

To achieve these goals and to gain a better understanding of women's and men's narratives regarding women's experiences in an extremely gendered field such as the Air Force, we resorted to using qualitative interviews. To the best of our knowledge, there are no qualitative studies that combine tokenism and gender dynamic issues in an integrated way in order to better understand the situation of women in the armed forces, and in this sense, we hope to obtain important and innovative data from the interviews.

\subsection{Participants}

Sixteen individual semi-structured interviews were conducted with members of the Portuguese Air Force: Eight men and eight women, with ages ranging between 19 and 54 years $(\mathrm{M}=35.88$; $\mathrm{DP}=10.94)$, with the female interviewees slightly younger $(\mathrm{M}=32.63$ years, $\mathrm{DP}=8.07)$ than their male peers $(\mathrm{M}=39.13$ years, $\mathrm{DP}=12.93)$. All interviewees were Portuguese, and their marital status was very diverse (6 single participants, 8 married/living with a partner, and 2 divorced).

Regarding their professional roles and rankings, the Air Force, based on a vertical rank structure, is founded on levels of hierarchic authorities with six main professional categories, from the top downwards: Officer generals, higher officers, captains and subalterns, sergeants, regulars, and recruits (Air Force 2019). These categories subdivide into more specific categories including various specialist fields. This sample includes five men from the Supply field (one male Higher Office, one female Captain Subaltern, and three male Sergeants); one woman from Aeronautical Administration (Higher Officer); another from Accounting (Sergeant); two men from IT (one Sergeant and one Regular); a woman from Communications Operations (Regular); a woman from the Air Police (Regular); three women from the Secretariat and Service Support (one Sergeant and two Regulars); and one 
man who preferred not to provide this information in order to ensure his anonymity. The length of service of respondents ranged from 1 to 31 years (see Table 2). Interview participation was entirely voluntary in nature, and no reward or compensation was provided.

Table 2. Length of service of the military respondents by sex.

\begin{tabular}{cccc}
\hline Length of Service & Female & Male & Total \\
\hline$<1$ year & 1 & 1 & 2 \\
$1-15$ years & 4 & 2 & 6 \\
$15-31$ years & 3 & 3 & 2 \\
$>31$ year & - & 2 & 16 \\
Total & 8 & 8 & 2 \\
\hline
\end{tabular}

\subsection{Procedure}

Our purposive sample was selected following a procedure that began with a formal request to the Air Force General-in-Command to conduct scientific field research. This request was submitted via email through the Air Force Psychology Centre and included detailed information about the research objectives, study plan, and methodology. After formal institutional approval, the Chief of Service selected a unit that matched the desired profile. These selected military professionals were all contacted, given the required information about the study, and asked to voluntarily participate. This selection process resulted in the present group of 16 interviewees from the same unit in the Lisbon metropolitan area. The interviews took place between 16 and 24 April 2019.

Interviews were conducted in the auditorium of the unit in the presence of a Major who was assigned to this task and was usually on duty at this location. Prior to the start of the interview, a consent form designed following the guidelines of our university's Ethics Committee was presented, read, and signed. This document properly informed the objectives of this study, the applicable confidentiality, and anonymity, and included a request for permission to record the interviews. Despite the informal setting and anonymity guarantees, the Major's presence could not be completely ignored and may have had an impact on the respondents' willingness to answer openly. Findings should be analyzed in light of this limitation. The average duration of the interviews was approximately $48 \mathrm{~min}$, and all 16 interviews were fully transcribed and analyzed.

\subsection{Instrument}

Demographic data were collected using a brief questionnaire (e.g., gender, age, specialty field, military position, seniority, and length of service). The script for the interviews was written in accordance with the literature review on the subject and specifically addressed the underrepresentation of women in the military in Portugal, the reasons for this occurring, and the impact of tokenism in this professional context. The script was adapted considering the gender of the participants. However, both versions focused on gender imbalance and inequality in the Portuguese Air Force and aimed to identify women's experiences and coping strategies, or men's perceptions of women's experiences in the Air Force.

\subsection{Analytical Strategy}

The content of the interviews was then subjected to thematic analysis (Braun and Clarke 2006), a method that allows for the "identification, analysis, and reporting of patterns (themes) in the data" (p. 79), as well as the identification of subthemes within the analyzed themes. Among the advantages of this method of analysis is its flexibility, as it allows us to organize the collected data in such a way that the data themselves provide a set of arguments that can be used as a framework. However, in order for this not to become a limited method of analysis, the authors suggest the definition of certain criteria and the development of a theoretical framework to support the results obtained. Braun and Clarke (2006) present a script for conducting a thematic analysis, in which they highlight 
six different phases of the analysis and point out the importance of going back or forward in these phases whenever necessary. These phases correspond to: (i) Getting familiar with the data, i.e., transcribing the interviews, reading the data, and jotting down initial ideas; (ii) systematically coding the data and identifying the codes present; (iii) defining and organizing these codes according to relevant themes; (iv) reviewing the themes in light of the coded excerpts and the dataset, and creating a thematic analysis map; (v) a re-examination of the themes, their specifics, and the names assigned to them; and finally, (vi) the preparation of the report relating the analysis conducted to the defined research questions and relevant literature, including the selection and final analysis of the interview excerpts that reflect the most representative experiences of the identified themes.

Framing our data in a social-constructionist perspective (Nogueira 2001), which understands texts and discourses as constructions of reality, anchored in social, political, historical, and cultural contexts (Gergen 1973), we coded the interview material through a largely deductive analysis, anchored in the literature on the topic (Braun and Clarke 2006) of tokenism from a gender perspective, but also through a partially inductive analysis, due to the possibility of identifying unexpected themes within the scope of our theoretical framework. The entire analysis was conducted in Portuguese; excerpts selected to illustrate the themes and subthemes were translated into English.

\section{Findings}

Analysis of the interviews allowed us to identify four main themes (see Table 3): Awareness that the Air Force is a masculine world; perceptions of gender dynamics; barriers to gender equality; and coping strategies.

Table 3. Themes and subthemes.

\begin{tabular}{|c|c|}
\hline Themes & Subthemes \\
\hline \multirow{2}{*}{$\begin{array}{l}\text { Awareness of the Air Force as a Masculine } \\
\text { world }\end{array}$} & Horizontal Segregation \\
\hline & Vertical Segregation \\
\hline \multirow{2}{*}{ Perception of Gender dynamics } & Regulations \\
\hline & Historical and cultural context \\
\hline \multirow{4}{*}{ Barriers to gender equality } & Visibility \\
\hline & Polarization \\
\hline & Assimilation \\
\hline & Misogyny \\
\hline \multicolumn{2}{|c|}{ Coping strategies } \\
\hline
\end{tabular}

\subsection{Awareness of the Air Force as a Masculine World}

The first theme conveys the awareness that the Air Force is a masculine world and includes two subthemes that focus on issues of horizontal and vertical segregation (see Table 3).

The first subtheme focuses on the existence of horizontal segregation in the Air Force, and it is a very prevalent theme that comes up in every interview. It includes the perceived reasons for these asymmetries, namely the way military occupations are traditionally perceived in society as being more closely associated with men than women. While recognizing that this reflects a changing reality, interviewees overwhelmingly described the Air Force as a "man's world":

We're still in a men's world. Irrespective of how in future years ( . . ) it may all be different, we are ... I am in a men's world inside here. I don't see that there's any distinction. They do not treat me any differently; not even when I joined up, that was over 20 years ago ( . . ) ), but I still think it's a men's world. (I1, female, 44 years) 
Serving in the military, to society it is still for a man, not for a woman. And, for us, whether we like it or not, this also grows on us a bit. (I8, female, 28 years)

In addition, respondents identified a number of possible explanations for the horizontal segregation identified in this occupational context, naming the following: (i) The different socialization and educational backgrounds of men and women; (ii) the belief that women may not be able and/or capable of meeting the physical demands of the job; (iii) the belief that women are better suited to certain specialties, namely driving, administrative tasks, nursing, and supply logistics; (iv) the observation that women do not always have the opportunity to obtain permanent contract status; (v) the argument that most women want to be mothers and/or prioritize their families and therefore do not want to over-commit to a profession that not only involves risk but can also put them in harm's way, such as the Air Force; and (vi) the recognition of the existence of historical bias in relation to the preferred areas for promotion, which have traditionally been those disciplines that focus on operational areas where women are less likely to be found:

Boys are used to running around with guns and dashing from one place to another to play some other type of game. Girls are more used to taking care of themselves, caring for the house (...) reading more, studying (...). They have different childhoods, which leads perhaps too easily to how a boy would want to get involved in an adventure such as this and a girl would ponder (... ). And, perhaps, they [women] don't see that many benefits in joining up. (I13, woman, 25 years)

I don't think that every woman... is available. Sometimes, it's not just psychologically, it's the physical capacity to get into the armed forces because it's one of the things that, as a serving military, we have to be ... fairly physically fit. (I2, man, 39 years)

In terms of recruitment, I think that, very often, ( . . ) the specialist areas that are publicized are the operational areas and that demand even more physically, than the other specialties ( ... ). This might be one of the motives for having more men applying and getting in than women, isn't it? (I16, woman, 40 years)

The second subtheme stems from the perception that there is vertical segregation in the Air Force. Nevertheless, respondents saw a positive change in recent years compared to the early days of women in this career field, especially with the advancement of some women to senior positions. However, interviewees still mentioned difficulties in implementing change in the military structure and confirmed that this is a slow and lengthy process. The importance of highlighting cases of success was also emphasized as a form of incentive for women to consider reaching higher positions in military institutions based on these exemplary cases:

There are increasingly more women competing, increasingly more women in higher positions but many are still not there (...). They are, in this moment, in key management points. There are already women there. There's a woman in this department, there's another woman in another department (...), while five years ago, in these places, there were only men. (I1, woman, 44 years).

I think the Air Force is the branch with the most women and I think that the Air Force was the first branch with a woman in the post of General and is going to be, perhaps, in the next few years, the branch with the most female Generals. My former Commander was a woman (...). And I see all this as more natural because when we take up the post, it's for the competence the person has and not for their sex. (I3, man, 44 years) 


\subsection{Perception of Gender Dynamics}

The second main theme (Table 3) covers gender discourses in the Air Force and spans two subthemes focusing on Air Force regulations and their evolution in historical and cultural context.

The first subtheme emphasizes the ways in which the Air Force tends to be a highly standardized environment in which both men and women are treated in a very formal manner. This treatment is very similar for both men and women, unlike what can happen in other civilian organizations where applications, evaluations, functions, promotions, salaries, and parental leave can be less standardized and potentially more subject to gender inequality. Although there were many inconsistencies in the issues that were brought up in the interviews, they did show that coexistence and compliance with the rules are expected for both men and women in the Air Force:

At the military level, there is no lack of equality in this aspect, the opportunities are open to both, the recruitment tenders are open and in which people compete on an equal basis. There are no numbers here, the wages are the same (...). Progression through the ranks is equal, it's therefore all within the rules $(\ldots)$. Military society is somewhat closed in relation to civil society, but it is not a macho society. (I14, man, 53 years)

Perhaps, out of all the places where I've already worked (...), this was the place where I felt that I was not being ignored or discriminated against for being a woman. ( ... ). From the phase in which we applied, up until actually being here, it's what I told you. It's not due to being a woman or for being a man ( . . ). Sometimes, it's good to be treated almost as if we are a number and to look only at the results without knowing whether it's a man or if it's a woman. (I16, woman, 40 years)

Furthermore, some respondents illustrated this equally strict adherence to norms and rules with their own experiences, namely in relation to uniforms and their general appearance (e.g., both sexes should be careful about the color they dye their hair with, although men must also keep it short, and women may wear their hair long if it is neatly tied back).

Respondents acknowledge a positive evolution in the professional context that has occurred historically and culturally since women were first contracted about three decades ago. This subtheme was raised in several interviews and underscores the social context that prevailed when women arrived in the Air Force was a very closed, sober, and masculine environment that was not entirely prepared to accommodate women and address their specific needs. The arrival of women caused some negative reactions, especially among those who rejected their integration and saw it as something negative but were still forced to get along with them. Considering the lack of real structural and organizational preparation for the entry of women, this change is perceived as successful, bringing changes for the better, not only for the mentality of the armed forces but also for society in general. For example, interviewees noted important improvements in infrastructure that previously hindered women's daily lives (e.g., accommodations suitable for both sexes), but also changes in socialization practices (which often adopt a stereotypical gender perspective), believing that the presence of women contributes to less aggressive, more harmonious inter-group relations:

Women, on joining the Armed Forces, came to change them for the better. It's no longer only brute force, as military forces were once perceived, it achieved a middle ground. There's that brute force but also a bit of delicacy. I think that was a good symbiosis, the women coming into the Armed Forces ( ... ). (I2, man, 39 years).

At the beginning, there was an adaptation, of course there was, as there had to be made adaptations to the accommodations. There was adaptation to the mentalities. Because this was a very ... it was really a very ... macho society. 
There were only men in here ... and, suddenly, the first woman appeared and for those who'd already been here without any such contact, there was a certain shock. However, afterwards, things began to adapt. (I14, man, 53 years)

\subsection{Barriers to Gender Equality}

The third major theme (Table 3) relates to barriers to gender equality in the Air Force and includes four subthemes clustered around visibility, polarization, assimilation, and misogyny.

Regarding visibility, discourses were heterogeneous and occasionally contradictory. Respondents attributed at least two different meanings to visibility: On the one hand, they acknowledged that in lower hierarchical positions, the dehumanizing factor was very strong and therefore gender did not have particular visibility (e.g., "a soldier is a soldier" regardless of whether he is a man or a woman"); on the other hand, they acknowledged that this could have an impact in higher hierarchies. In some interviews, it was argued that men, who form the vast majority, are more 'visible', in the sense that they are more represented in each rank. Nevertheless, interviewees acknowledged that women, as a minority, were ultimately more 'visible' in the sense that they received more attention to their failures or successes, particularly early in their military careers, and were subject to closer scrutiny than men. This potential visibility was seen to be highly dependent on the type of leadership to which these women were subjected, particularly whether their superiors were male or female. In this sense, respondents reported the perception that women were more often criticized and/or punished compared to their male counterparts, whether for mistakes made or for their successes, and this perception forms another subtheme-polarization. Some female interviewees also admitted that they felt pressured to perform at a higher level, particularly the need to show that they could achieve the same standards as men. The content of the interviews confirmed these claims:

At the maximum scale, there, they attribute more relevance to an error, or something done in a spectacular way by a woman more than by a man because, well, they think that 'Ah, this is not normal' (laughter), or they would say 'Look, look, look, did you see, did you see. She did it wrong, she did it wrong. I was waiting for her to' than 'Look, did you see? She did something very good'. I think that this becomes more obvious for women ( . . ) than for men. (I4, woman, 31 years)

Other interviewees, however, perceived a tendency in the Air Force to favor and/or be more forgiving of female soldiers. They spoke of the existence of old-fashioned, paternalistic ways of treating female military personnel, as if they needed protection or as if they should be treated gentlemanly. In addition, two important aspects were perceived: That it is easier to remember women's personal information (e.g., their names) because they are so few among so many men and that there is a trend to refer to women not by their last names, as is common in military circles, but by their first names:

A woman is in focus from the very moment when she ... if there is a group of persons in which the number is only minimal ( ... ), but even more reduced in terms of the number of women, thus, the group of women always ends up standing out in whatever place they might be. (I13, woman, 25 years)

Research (Files et al. 2017; Atir and Ferguson 2018) suggests that gender influences the way we talk about professionals, so men are more likely than women to be addressed by their last names and that this gender bias may have consequences for women, leading to a poorer assessment of status and to less likelihood of being seen as having merit or of being able to win awards (Atir and Ferguson 2018). Differential formality in treatment may also amplify women's isolation, marginalization, and professional discomfiture (Files et al. 2017).

The subtheme of the construction/deconstruction of boundaries was found in the interviews when participants talked about the language used in the presence of women (including during leisure time). Interviewees often referred to conversations between peers and the type of language used in the presence and absence of women, as well as when a 
woman was called out by a supervisor. They emphasized the less-harsh language and a more cautious and respectful tone towards women displayed by some of the older professionals. Nevertheless, when participants mentioned moments of informal socialization between peers, they indicated that such treatment was often omitted, and often without any particular care or distinction regarding gender. Women are seen as one of the "boys" in moments of leisure and treated only as "soldiers". In these situations, some women tend to feel uncomfortable and remove themselves from the situation or draw attention to their presence, while other women use the same kind of language or humor as men.

Most interviews also mentioned differential treatment in terms of physical demands and evaluation standards, with parameters in terms of men's and women's physical abilities and in terms of orders given to soldiers as adjusted. Even the pressure exerted by leaders is seen as different for men and women. Respondents felt that men are pushed to their limits compared to women, to whom they have to be more considerate of their physiological well-being (e.g., menstruation):

One thing is a military girl, another thing is a civilian girl. They begin to lose their concerns with the military girl (...), that is, we end up ... there are times when we are somewhat invisible, that they deal with us as if we were ... as if boys ... as if we were men, just like them. They are no longer inhibited, sometimes, from having any type of conversation (laughter), until they forget. (... ) Afterwards, when they sometimes get the notion that they've been pushing it a bit, 'Ohhh.' Yes, that's it ... in this sense, it's just that I think that they, sometimes, show a little bit more care. (I4, woman, 31 years)

In addition, some interviewees expressed biased perceptions, stating that men and women should be targeted for different tasks, functions, and even missions because of their different abilities and skills. Some female interviewees acknowledged that they experienced differential positive treatment when they became mothers while understanding that the desire to raise a family was a barrier to accepting women in the Air Force and integrating them into specific roles. Some female interviewees referred to this dual position as an officer and as a woman as a negative factor. Some mentioned that they had difficulty making their voices heard as a woman:

It's all more facilitated. We also have to take into account they are women, they don't have the same physical capacities ... and psychological (... ). Women are more cushioned in this aspect. A man is really for pushing to the limit and a woman $(.$.$) is also for pushing to the limit but more calmly, not so aggressively.$ And, in this aspect, there is a difference, there is differentiation. (I6, man, 19 years)

The assimilation subtheme was also evident in the discourse mentioned above regarding the de-individualization of the serving military, who were asexualized and trained to function and obey mechanically, regardless of gender. These discourses of total assimilation through dehumanization contrasted with the narratives of some interviewees who portrayed the assimilation of women in a more stereotypical manner, as described above. In this view, women are perceived as having accepted specific roles because they are more physically fragile, sensitive, maternal, responsible, organized, and detailed, and for these reasons, they are sometimes restricted to certain functions and roles. According to these comments, women were particularly suited to writing long and detailed documents or hosting children on guided visits to the unit, among other duties. Some interviewees also claimed that women could occasionally be deployed to rear-guard duties, while men were more easily deployed to hostile environments, undertook more aggressive tasks, and engaged in physical confrontations, because of their supposedly greater adventurousness and courage. It was also accepted that there should be gender differences in specialist areas. Some fields were considered more suited to men because of their more operational characteristics (e.g., pilots, navigators, aircrew), due to differences in physical ability. This replication of traditional stereotypes of masculinity and femininity expressed in the discourses was not perceived as biased by the respondents: 
I remember how here, around Christmas time, some of the women soldiers were selected $(\ldots)$ to welcome the schools that come and visit, the kids and so forth. Ah well, really. Perhaps they have a better vocation and have more of that maternal power, don't they? And so, they get chosen to take these children around, for example. Perhaps, they have things that, well, they are better at than males, don't they? There are jobs, for example, that need more details, more attention ... I think that, in this aspect, they are better but, well, this has to do with performing the roles and (...) the bosses themselves have to show greater awareness towards this (... ), when they distribute the tasks! (I7, male, 47 years)

The advantage that I see [of being a man] is the greater availability because, whether or not we want this, in the family environment, a woman always has more obligations, if you will, than a man, has greater availability about being present for the children while a man is always a bit freer from such functions. Therefore, he has greater availability (...), physically, if it is a mission, I don't know, a mission in a conflict zone, a more aggressive deployment ( ... ), perhaps the man would still be more adventurous and with fewer problems over fear, physical issue that are still instilled into women. That she, if she's left further back, in the rear guard, of the function or the mission, she'll be more easily able to perform than if she's placed on the front line where she might have to $(\ldots)$ perform more aggressive functions. (I14, man, 53 years)

Some respondents also stated that some women tend to adopt the male model (e.g., short haircuts and changes in their appearance and speech), which raises the hypothesis that these behaviors serve as a kind of adaptation strategy so that they are seen as closer to the ideal of the military professional archetype. It could even be that some women feel so inhibited by the context that they display more masculine characteristics just to fit in. However, there was also an argument among the interviewees that, unlike in the past, women today do not need to adopt such an attitude if it does not fit their personality. Some even emphasize their feminine side, pay attention to their appearance, wear makeup, and sometimes exceed the limits set by the rules of physical appearance.

As for the last subtheme, misogyny, there was indeed some discourse that could fit this label that contributes to gender inequalities in the Air Force. On the one hand, there seems to be a perception, even among female interviewees, that women are more confrontational than men and that a female environment could lead to more confusion and competitiveness and even create changes that are detrimental to the institution itself (e.g., regarding general rules for military dress). It is also possible to identify discourses in which men view women as pickier and more critical in their interactions, confronting and questioning them, and occasionally being significantly crueler to other women when comparing how men treat their female colleagues:

One of the good things that I like about being in the armed force is also working amid many men because many women (... ) are terrible. I think that women end up being far more competitive (... ). And, afterwards, many women on various perches, it depends ... I don't know what it would be like. (I1, woman, 44 years)

Women were always far worse. Even in this first period, the women were worse to women ... than the men were to the women. While the men gave the benefit of the doubt to women, a woman ... castrated is not the correct term but, put the brakes on, very often, thus the reactions ( ... ). The women were terrible when hazing other women. (I3, man, 44 years)

\subsection{Coping Strategies}

The final main theme (Table 3) summarizes some of the coping strategies used by these women in the Air Force. Some of the female respondents indicated that they did not feel the need to consciously use a particular coping strategy in this male-dominated environment. Several female interviewees reported active efforts to behave more calmly 
in uncomfortable situations and/or comments in order to gain the respect of their peers, but also to increase their chances of being respected; others described extra effort to make sure they strictly followed orders and regulations in order to avoid receiving derogatory comments (e.g., regarding make-up and accessories, such as earrings); others express a need to be frontal and make themselves heard at a particular time so as not to let everything pile up only to explode later, but also a desire to listen and learn what is on people's minds. A third discourse relates to setting certain boundaries to separate their professional and private lives and always maintaining a respectful and credible attitude:

Normally, my strategy is to try to breathe deeply and, well, 'you come here tomorrow, if necessary, then set out your point of view if you think that's appropriate. Now, you're going to have to try and assimilate this so that you're able to speak more calmly', because if not ( ... ), if the thing was already not very good, then it's only going to get worse, isn't it? Therefore, it's not really worthwhile. (I1, woman, 44 years)

What I do is that I respect them, and I hope that they respect me ( ... ). That's all that I ask for, mutual respect. This is the main precaution that I have, and I hope that's the main care that they take with me. That's it. Respect ... (I4, woman, 31 years)

Some male respondents did not think it was necessary for women to adopt specific strategies to integrate into today's Air Force, assuming that organizational changes in culture were already inclusive enough. They believe that women's entry into the military is due to individual characteristics and not the military organizational culture. However, others report that female soldiers have had to adapt in order to achieve their goals, but also that they are, in some ways, manipulative and seductive in their dealings with men:

I never thought that [women] might feel the need to have a strategy to fit into the surroundings. I always saw the situations as something natural. More closely related to the attitude and the way of being of the person than actually being a minority gender. No, no, I don't see the situation in that way. (I5, man, 33 years)

I think that [women] try and integrate, try and understand ( . . ), adapt themselves to the way of being and the way of doing that there is among the men ( ... ). They try and show their feminine side ( ...), of caring or (laughter) feminine delicacy that is able to captivate the man because it's normal. We, if we are dealing with a work colleague who is a woman and then she is delicate with us, we all like it ( . . ). And I think that women do use this a bit, a little delicacy ( ... ). I've seen some of them do this. Yes, yes. To be well accepted, so that they do not get into difficulties, well, they try and please and try and be pleasant. (I14, man, 53 years)

\section{Discussion}

This article focuses on gender dynamics in the Portuguese Air Force, a male-dominated professional context. In particular, it analyzes the tokenism experiences of female members of the Air Force, as well as the perspectives of their male counterparts, who belong to a traditionally dominant group in the military, and the strategies women use to cope with their situation. Using an approach that combines tokenism and gender dynamics (e.g., Acker 1990; Amâncio 1997; Connell 2006), this article seeks to understand how these findings align with the phenomena of tokenism identified by Kanter $(1977,1993)$, namely by identifying themes of high visibility, polarization, and assimilation.

We emphasize that all respondents articulated perceptions of gender imbalance in the Air Force. Although the Air Force was the first branch of the armed forces to promote gender equality and open recruitment to women in Portugal about three decades ago and is still the branch that has more women in its ranks today, some patterns of gender segregation can be identified that correspond to Kanter's $(1977,1993)$ description of tokens. These patterns extend to both the horizontal and vertical levels: At the horizontal level 
due to the smaller number of women in the military, and at the vertical level since the number of women in higher hierarchical positions is far below that of men, on the grounds that the relatively recent recruitment data of the former remain valid. Indeed, Acker's (1990) perspective largely coincides with the views of these male and female respondents, as in this author's view, each of these phenomena results, to a greater or lesser extent, from the gender divisions established by the structures and processes of the organization, thus contributing to the perpetuation of these inequalities not only in relation to work and employment, but also in relation to family and state. Furthermore, this allows men to continue to be perceived as more capable and suited to positions of authority, which Connell (2006) argues does not arise from an organizational logic, but rather from the gender relations that are established, and structure society based on the meanings and specific positions assigned to men and women within the overarching auspices.

Although the opinion of the interviewees of both sexes is unanimous regarding the existence of predefined rules that promote gender equality in the Air Force, and on the acknowledgement of improvements considering the historical and cultural background, this study shows that women's experiences are still very similar to those mentioned by Kanter (1977, 1993). Within this framework, we highlight how the discourses of both male and female respondents appear to conform to what Amâncio (1994) has termed the paradox of discrimination. While females do not always report being the target of peer resistance or discrimination, males confirm this claim, mentioning these situations during their interviews whether in relation to themselves or their female peers. However, these are often attributed to individual occurrences, due to personality traits. Another protective layer is added by establishing that these situations occur outside their unit or their specialist field, and much less so in the present day.

In terms of visibility, it seems that the fact that women are less numerous than men in the Air Force means that they stand out and that it is easier to remember their first names, for example. However, this also can be seen as a form of gender bias with potentially negative consequences for women. In addition, the high visibility seems to lead to increased pressure to perform with an increased need to compete with their peers and demonstrate their abilities, while also greater critical scrutiny of their successes and failures, at times making them the target of negative comments from male colleagues, although they are also subject to outdated expressions of chivalry and paternalism from some men.

Regarding the theme polarization, there is differential treatment of women in the Air Force particularly in terms of some men's use of less forceful and more cautious language when it comes to social interactions or when women are called to attention. In terms of the lower physical demands placed on female soldiers in physical tasks and assessments, greater care is taken not only in interactions but also at the level of functions and missions to which women are assigned. While the women interviewed rarely spoke directly about barriers to women joining the Air Force or being leaders, examples of difficulties were frequently mentioned. Becoming mothers or intending to do so is one of the examples cited to reinforce the sense of women's exclusion.

When speaking of assimilation, some respondents revealed strong stereotypes associated with the category "women" to describe what it is like to be a woman in the Air Force by ascribing stereotypical characteristics (e.g., maternal, fragile, and sensitive). The male professionals' descriptions tended to use adjectives that fell within the scope of what it means to serve in the military (e.g., adventurous, courageous, strong).

Furthermore, some of the characteristics attributed to women, as well as some of the situations described by male and female respondents, support the contention that women are in a "role prison" (Kanter 1993), that there are certain tasks, functions, or missions that are considered better suited for women because they are considered by men to be "the weaker sex" in physical terms. In terms of assimilation, there is also the narrative that some women adopt masculine traits (as an adaptation strategy or out of preference) to be more similar to the traditional military "ideal". Other narratives evoke another stereotypical 
belief, that women display feminine traits to gain advantages by being seductive. This heterogeneity is seen as peaceful and not exclusionary.

\section{Conclusions}

Overall, the findings show that the effects of tokenism not only lead to women receiving more attention and visibility in everything they do, but also to inequalities and different treatment between men and women (Santos et al. 2015). This seems to be because women are primarily perceived as 'feminine' and are expected to act according to their gendered roles. Occasionally, respondents contextualized this role with their family roles or with emotional traits (Amâncio 1992; Amâncio and Oliveira 2006). This generalization inevitably affects interactions within the organization and contributes to the continued emphasis on differences between women and men in the Air Force, whether in terms of physical abilities, aptitude for certain tasks, or different roles and missions (Acker 1990; Amâncio 1992; Connell 2006). This contributes to their efficacy being frequently questioned, due to the belief that there are physical and psychological differences between women and men (Carreiras 2013), not on an individual level, but as an entire social group, which hinders changes in the social representation of military personnel (Amâncio 1992). Furthermore, women's experiences of serving in the Air Force, as well as the perspectives of their male counterparts, reveal misogynistic discourses that reflect stereotypical ideas about women. This is a major barrier to gender equality in the Air Force.

We consider that the data we gathered in the interviews were extremely enriching, but nevertheless, it would be useful to collect this type of information about women in the Air Force outside the work context and without the supervision of a superior. Although the interviewees showed great openness in their answers, they may have restrained their opinions due to pressure from the context.

Despite these methodological limitations and the very nature of the qualitative approach, our findings clearly show that despite the prescriptive pressure at the organizational level for the existence of gender equality in the Armed Forces, the socio-normative patterns of gender and the gendered attribution of "feminine" and "masculine" roles to the sexes is still adopted and recognized by both men and women.

Moreover, although women who find themselves in the position of tokens in the Air Force are not always aware of the reasons that lead them to adopt certain strategies in dealing with gender inequality, they do have some strategies related to being women in an atypical context: They express the need to push themselves and try harder to be heard, to avoid unwanted comments, and to prove themselves, in order to gain and maintain respect and credibility in the organization. It is also clear that women try to manage these positions and the normative expectations of femininity in an instrumental way, but without seeking to be real agents of change. In this sense, in their discourses, women adopt a rather conformist and not very active stance in their role for the modification of the status quo.

In summary, despite the Air Force's increasing efforts to make its environment gender equal, women in fact face obstacles that, although not always visible, impede their path and differ in several respects from that of their male counterparts. However, these obstacles do not result only and exclusively from their underrepresentation, but also from the historical gender hierarchy that legitimizes asymmetrical social representations in this professional context (Acker 1990; Amâncio 1992) and that reflects the prevailing gender order (Connell 2006) and contributes to gender inequality in this environment.

Future research on women's experiences in the Armed Forces may consider the usefulness of the joint perception of the tokenism perspective with the understanding of gender dynamics in society, in order to understand how processes of deconstruction of stereotyped roles in the military organizations can be accelerated. In these processes, it will always be necessary to underline the differential experiences of women in this context, but also in society, and to address their historical under-representation in these institutions. It is also necessary to empower women to feel that they can play an active role in these processes, but also to encourage men to work as collaborative agents for change. 


\begin{abstract}
Author Contributions: Conceptualization, M.H.S.; methodology, M.H.S., and P.M.; software: M.H.S and P.M.; validation: M.H.S.; formal analysis, P.M.; investigation, P.M.; resources, M.H.S., and P.M.; writing—original draft preparation, P.M.; writing-review and editing, M.H.S., and R.B.C.; supervision, M.H.S.; project administration, M.H.S.; funding acquisition, M.H.S.; All authors have read and agreed to the published version of the manuscript.
\end{abstract}

Funding: This research was funded by the FCT—Fundação para a Ciência e Tecnologia, I.P., under the Transitory Norm-DL 57/2016/CP 1359/CT0023, provided to the first author, and under the PEST Grant number UID/PSI/03125/2013, provided to the third author.

Informed Consent Statement: Informed consent was obtained from all study participants.

Data Availability Statement: Not applicable.

Acknowledgments: The authors would like to thank Fundação para a Ciência e a Tecnologia (FCT) and all the participants in our study.

Conflicts of Interest: The authors declare no conflict of interest.

\title{
References
}

Acker, Joan. 1990. Hierarchies, jobs, bodies: A theory of gendered organizations. Gender and Society 4: 139-58. [CrossRef]

Air Force. 2019. Postos e Distintivos. Available online: https:/ / www.emfa.pt/p-201-postos-e-distintivos (accessed on 10 September 2020).

Almeida, Iris. 2006. A dimensão de género na investigação criminal: Um estudo na Polícia Judiciária. Master's dissertation, Instituto Universitário de Lisboa (Iscte-IUL), Lisboa, Portugal.

Amâncio, Lígia. 1992. As assimetrias nas representações do género. Revista Crítica de Ciências Sociais 34: 9-22.

Amâncio, Lígia. 1994. Masculino e feminino: Construção social da diferença. Porto: Edições Afrontamento.

Amâncio, Lígia. 1997. The importance of being male: Ideology and context in gender identities. Revue Internationale de Psychologie Sociale 10: 79-94.

Amâncio, Lígia. 2005. Reflections on science as a gendered endeavour: Changes and continuities. Social Science Information 44: 65-83. [CrossRef]

Amâncio, Lígia, and João Manuel Oliveira. 2006. Men as individuals, women as a sexed category. Implications of symbolic asymmetry for feminist practice and feminist psychology. Feminism and Psychology 16: 35-43. [CrossRef]

Amâncio, Lígia, and Maria Helena Santos. 2021. Gender equality and modernity in Portugal. An analysis on the obstacles to gender equality in highly qualified professions. Social Sciences 10: 162. [CrossRef]

Atir, Stav, and Melissa Ferguson. 2018. How gender determines the way we speak about professionals. Proceedings of the National Academy of Sciences 115: 7278-83. [CrossRef]

Bettio, Francesca, Alina Verashchagina, Ingrid Mairhuber, Danièle Meulders, Iskra Beleva, Alexia Panayiotou, Alena Křížková, and Ruth Emerek. 2009. Gender Segregation in the Labour Market: Root Causes, Implications and Policy Responses in the EU. Luxembourg: Publications Office of the European Union, Available online: https://op.europa.eu/pt/publication-detail/-/publication/39e6 7b83-852f-4f1e-b6a0-a8fbb599b256 (accessed on 11 January 2022).

Braun, Virginia, and Victoria Clarke. 2006. Using thematic analysis in psychology. Qualitative Research in Psychology 3: 77-101. [CrossRef]

Budig, Michelle J. 2002. Male advantage and the gender composition of jobs: Who rides the glass escalator? Social Problems 49: 258-77. [CrossRef]

Carreiras, Helena. 2004. Mulheres em contextos atípicos: Lógicas de exclusão e estratégias de integração feminina nas Forças Armadas. Etnográfica 8: 91-115. Available online: https://repositorio.iscte-iul.pt/handle/10071/13812 (accessed on 20 September 2020).

Carreiras, Helena. 2006. Gender and the Military: Women in the Armed Forces of Western Democracies. London: Routledge.

Carreiras, Helena. 2011. Igualdade de oportunidades nas Forças Armadas. O papel das políticas de integração de género. Cuestiones de género: De la igualdad y la diferencia 6: 97-116. [CrossRef]

Carreiras, Helena. 2013. Mulheres, direitos e eficácia militar: O estado do debate. Revista Militar 2536: 477-95. Available online: http:/ / www.revistamilitar.pt/artigopdf/826 (accessed on 30 September 2019).

Casaca, Sara Falcão, and Johanne Lortie. 2017. Handbook on Gender and Organizational Change. Turin: International Training Centre/International Labour Organization.

Cognard-Black, Andrew J. 2004. Will they stay, or will they go? Sex-atypical work among token men who teach. The Sociological Quarterly 45: 113-39. [CrossRef]

Connell, Raewyn. 2002. Gender. Cambridge: Polity Press.

Connell, Raewyn. 2006. Glass ceilings or gendered institutions? Mapping the gender regimes of public sector worksites. Public Administration Review 66: 837-49. Available online: http://www.jstor.org/stable/4096601 (accessed on 20 June 2019). [CrossRef]

Delgado, Catarina. 2016. Dinâmicas de género na Polícia Judiciária: Análise em contexto maioria e minoria. Master's dissertation, Instituto Universitário de Lisboa (Iscte-IUL), Lisboa, Portugal. 
Evertson, Adrienne, and Amy Nesbitt. 2004. The Glass Ceiling Effect and Its Impact on Mid-level Female Officer Career Progression in the United States Marines Corps and Air Force. Monterey: Naval Postgraduate School, Available online: https://calhoun.nps.edu/ handle/10945/1711 (accessed on 10 September 2021).

Fachada, Cristina, Nuno Quirino Martins, Maria João Oliveira, Raquel Quintas, and Ana cristina Telha. 2013. Mulheres nas forças armadas portuguesas: A realidade da força aérea. Revista Militar 2536: 445-75. Available online: https://www.revistamilitar.pt/ artigopdf/825 (accessed on 10 September 2020)

Files, Julia A., Anita P. Mayer, Marcia G. Ko, Patricia Friedrich, Marjorie Jenkins, Michael J. Bryan, Suneela Vegunta, M. Christopher Wittich, A. Melissa Lyle, Ryan Melikian, and et al. 2017. Speaker introductions at internal medicine grand rounds: Forms of address reveal gender bias. Journal of Women's Health 26: 413-19. [CrossRef]

Floge, Liliane, and Deborah M. Merrill. 1986. Tokenism reconsidered: Male nurses and female physicians in a hospital setting. Social Forces 64: 925-47. [CrossRef]

Gergen, Kenneth J. 1973. Social psychology as history. Journal of Personality and Social Psychology 26: 309-20. [CrossRef]

Germain, Marie-Line, Mary J. R. Herzog, and Penny R. Hamilton. 2012. Women employed in male-dominated industries: Lessons learned from female aircraft pilots, pilots-in-training and mixed-gender flight instructors. Human Resource Development International 15: 435-53. [CrossRef]

Heikes, Joel E. 1991. When men are the minority: The case of men in nursing. Sociological Quarterly 32: 389-401. Available online: https:/ / www.jstor.org/stable/4120914 (accessed on 16 January 2019). [CrossRef]

Kanter, Rosabeth M. 1977. Some effects of proportions on group life: Skewed sex ratios and responses to token women. The American Journal Sociology 82: 965-90. Available online: https:/ / www.jstor.org/stable/2777808 (accessed on 16 January 2019). [CrossRef]

Kanter, Rosabeth M. 1993. Men and Women of the Corporation, 2nd ed. New York: Basic Books.

King, Anthony. 2016. The female combat soldier. European Journal of International Relations 22: 122-43. [CrossRef]

Kronsell, Annica. 2005. Gendered practices in institutions of hegemonic masculinity: Reflections from feminist standpoint theory. International Feminist Journal of Politics 7: 280-98. [CrossRef]

Lorenzi-Cioldi, Fabio. 1998. Group status and perceptions of homogeneity. European Review of Social Psychology 9: 31-75. [CrossRef]

Nogueira, Conceição. 2001. Um novo olhar sobre as relações sociais de género: Feminismo e perspectivas críticas na Psicologia Social. Lisbon: Calouste Gulbenkian Foundation and Science and Technology Foundation.

Ott, Marlies E. 1989. Effects of the male-female ratio at work: Policewomen and male nurses. Psychology of Women Quarterly 13: 41-57. [CrossRef]

Ridgeway, Cecilia L. 2011. Framed by Gender: How Gender Inequality Persists in the Modern World. Oxford: Oxford University Press.

Rimalt, Nova. 2007. Women in the sphere of masculinity: The double-edged sword of women's integration in the military. Duke Journal of Gender Law \& Policy 14: 1097. Available online: https:/ / ssrn.com/abstract=1092822 (accessed on 10 December 2021).

Santos, Maria Helena, and Lígia Amâncio. 2014. Sobreminorias em profissões marcadas pelo género: Consequências e reacções. Análise Social 212: 700-26. Available online: http://analisesocial.ics.ul.pt/documentos/AS_212_d04.pdf (accessed on 16 January 2019).

Santos, Maria Helena, Lígia Amâncio, and Patricia Roux. 2015. Numbers do not tell the whole story: Gender and medicine in Portugal. Women's Studies International Forum 53: 73-82. [CrossRef]

Santos, Maria Helena, Patricia Roux, and Lígia Amâncio. 2016. Expériences et stratégies de femmes investies dans un «monde d'hommes»: Le cas de la politique locale portugaise. Sociologia, Problemas e Práticas 82: 69-87. [CrossRef]

Segal, David R., and Mady Wechsler Segal. 2004. America's military population. Population Bulletin 59: 1-42. Available online: https:/ /www.prb.org/wp-content/uploads/2004/12/ACF1396.pdf (accessed on 14 September 2020).

Smith, Louisa. 2013. Working hard with gender: Gendered labour for women in male dominated occupations of manual trades and information technology (IT). Equality, Diversity and Inclusion 32: 592-603. [CrossRef]

Spangler, Eve, Marsha A. Gordon, and Ronald M. Pipkin. 1978. Token women: An empirical test of Kanter's hypothesis. American Journal of Sociology 84: 160-70. [CrossRef]

Watkins, Marla Baskerville, Aneika Simmons, and Elizabeth Umphress. 2019. It's not black and white: Toward a contingency perspective on the consequences of being a token. Academy of Management Perspectives 33: 334-65. [CrossRef]

Williams, Christine L. 1992. The glass escalator: Hidden advantages for men in the 'female' professions. Social Problems 39: $253-67$. [CrossRef]

Williams, Christine L. 1995. Still a Man's World. Men Who Do "Women's Work". London: University of California Press.

Yoder, Janice D. 1991. Rethinking tokenism: Looking beyond numbers. Gender and Society 5: 178-92. Available online: https: / / www.jstor.org/stable/189483 (accessed on 16 January 2019). [CrossRef]

Yoder, Janice D. 1994. Looking beyond numbers: The effects of gender status, job prestige, and occupational gender-typing on tokenism processes. Social Psychology Quarterly 57: 150-59. [CrossRef]

Yoder, Janice D., and Theodore W. McDonald. 1998. Measuring sexist discrimination in the workplace: Support for the validity of the schedule of sexist events. Psychology of Women Quarterly 22: 487-91. [CrossRef]

Yoder, Janice D., Jerome Adams, and Howard T. Prince. 1983. The price of a token. Journal of Political and Military Sociology 11: 325-37. 